\title{
Editorial to the special issue on resilience and vulnerability assessments in natural hazard and risk analysis
}

\author{
Sven Fuchs ${ }^{1}$, Margreth Keiler ${ }^{2}$, and Thomas Glade ${ }^{3}$ \\ ${ }^{1}$ University of Natural Resources and Life Sciences, Institute of Mountain Risk Engineering, Vienna, Austria \\ ${ }^{2}$ University of Bern, Institute of Geography, Bern, Switzerland \\ ${ }^{3}$ University of Vienna, Department of Geography and Regional Research, Vienna, Austria
}

Correspondence to: Sven Fuchs (sven.fuchs@boku.ac.at)

Received: 23 June 2017 - Published: 18 July 2017

Given the conditions of global environmental change such as outlined in the Fifth Assessment Report of the United Nations Intergovernmental Panel on Climate Change (Stocker et al., 2013), impacts from natural hazards on natural and human systems are manifest worldwide (Keiler et al., 2010; Field et al., 2014). Such impacts are the result of both the frequency and magnitude of the hazard and the exposure of the society or elements at risk, such as buildings or infrastructure lines (Keiler and Fuchs, 2016), as well as underlying dynamics (e.g. Malek et al., 2015; Fuchs et al., 2017). In recent years, the concepts of vulnerability and resilience have (again) become popular in environmental hazard and risk management. Ideas and concepts of vulnerability and resilience are used by various scholars from different scientific disciplines - as well as by practitioners and institutions - and hence are used in multiple disciplinary models underpinning either a technical or a social origin of the concept and resulting in a range of paradigms for either a qualitative or quantitative assessment, which is scale-dependent in either case (Hufschmidt and Glade, 2010; Birkmann et al., 2013; Ciurean et al., 2013; Sudmeier-Rieux, 2014). Despite the growing amount of studies recently published, current approaches are still driven by a divide between natural and social sciences, even if some attempts have been made to bridge this gap.

In acknowledgement of the different roots of disciplinary paradigms, methods determining structural, economic, institutional or social vulnerability and resilience should be interwoven in order to enhance our understanding of vulnerability and resilience, and to adapt to ongoing global change processes. Therefore, there is a need to expand our vision on hazard and risk management, integrating adaptation and mit- igation approaches into the broader context of related governance arrangements (Greiving and Glade, 2013; Thaler et al., 2016).

This special issue is based on contributions of session NH9.7 at the European Geosciences Union (EGU) General Assembly 2015 held in Vienna, Austria, on 12-17 April 2015 and some additionally invited contributions. The volume presents some recent studies to summarize the assessment of different types of vulnerabilities (e.g. social, personal, structural, economic, political, environmental) and resilience for different natural hazard phenomena. The main focus herein is to show different strategies based on developments from different disciplines and to discuss these according not only to similarities but also to differences. Taking the findings and results of four special issues that were recently published in NHESS and Natural Hazards (Glade and Birkmann, 2009; Fuchs et al., 2011, 2012; Fuchs and Glade, 2016) as a starting point, this special issue contributes with interdisciplinary articles that summarize the concepts of vulnerability and resilience by using regional case studies and findings from European research projects and beyond.

The special issue provides some insights into these issues and has a particular focus on different methods to determine vulnerability and resilience on a regional scale; as such it is independent from the often-published large-scale case studies where a further application of the respective method to other case studies is challenging due to the specific data requirements. The editors would like to foster a scientific discussion on such approaches in order to further stimulate the debate on vulnerability and resilience in natural hazard management. 
Assessing the number and locations of exposed people and elements at risk, such as buildings, is a crucial step in natural hazard risk management and emergency planning (Fuchs et al., 2015). Garcia et al. (2016) present an approach to overcome this gap in areas where sufficient census data are not available. Using dasymetric cartography, they show how such an approach may be used to better approximate the number of people exposed and how results may be used in vulnerability modelling for landslide risk.

Using data from the 2002, 2010 and 2013 flood events in eastern Germany, Dressler et al. (2016) approach the challenge of demographic transitions with an ageing society, frequent out-migration and low birth rates in disaster risk management. Using information from publicly accessible resources, they discuss how such population dynamics affect the performance of rescue services and how in particular rural areas are less resilient in terms of management performance.

Taking the example of North Caucasus ski resorts, Komarov et al. (2016) discuss how an increase in people at risk necessitates innovative methods for risk assessment. In areas where tourism infrastructure has rapidly developed, the number of exposed people will rise, and, simultaneously, vulnerability and risk are highly dynamic. Hence, risk mitigation needs improved methods in particular in areas with a lack of historical data on snow avalanche fatalities and risk, which in turn may result in a higher resilience of societies.

So far, vulnerability curves are widely used by practitioners in operational risk management to assess the physical vulnerability of elements at risk (e.g. Totschnig et al., 2011; Eidsvig et al., 2014). However, these curves often reveal a need to include specific characteristics of the buildings to improve mitigation in risk management. Using an indicator approach, Papathoma-Köhle (2016) presents a study on vulnerability in mountain hazard risk management. The need for a holistic framework for physical vulnerability assessment applicable by practitioners is emphasized, and a preliminary version of such a framework is presented. It is shown how the approach supplements vulnerability curves and matrices for a better understanding of the complex interaction between hazards and elements at risk (Papathoma-Köhle et al., 2017).

Castillo-Rodríguez et al. (2016) present a method to promote quantitative risk analysis to support local action planning against flooding. They provide a framework for local stakeholders, combining hazard mapping with vulnerability data with quantify risk in terms of annual affected population, potential injuries, number of fatalities and economic loss. A particular focus of their study is on population dynamics, which has also been claimed with respect to an enhancement in mountain hazard risk management and disaster risk management by Keiler et al. (2005, 2006).

Willis and Fitton (2016) review different approaches to assess social vulnerability to flood hazards. They demonstrate how three different quantitative methodologies (based on Cutter et al., 2003; Rygel et al., 2006; and Willis et al.,
2010) applied to the same England and Wales 2011 census data variables in the geographical setting of the 2013-2014 floods of the river Parrett catchment, UK, lead to notable differences in vulnerability classification. The findings of their study have implications both in how we convey the uncertainty of such vulnerability assessments and in the wider concern of flood defence management.

Keating et al. (2017) present a framework and tool for measuring community level resilience to flooding, built around the British Department for International Development (DFID) Sustainable Livelihoods Framework. By comparing pre-flood characteristics to post-flood outcomes, they aim to empirically verify sources of resilience. The authors conclude that there is an urgent need for the continued development of theoretically anchored, empirically verified and practically applicable disaster resilience measurement frameworks and tools. The availability of such frameworks will deepen the understanding of key components of disaster resilience and enhance the ability to quantify resilience over time.

Based on case studies from Norwegian municipalities, Eidsvig et al. (2017) propose a model for assessing the risk posed by natural hazards to infrastructure, with a focus on indirect losses and loss of stability for the population relying on the infrastructure. Focusing on a method for semi-quantitative analyses, a screening of possible scenarios of natural hazards threatening the infrastructure is performed, and the most critical scenarios are identified with respect to further quantitative assessment. The proposed semiquantitative method considers the hazard frequency; different aspects of vulnerability, including physical vulnerability of infrastructure; and the societal dependency on infrastructure. An indicator-based approach is applied, ranking the indicators on a relative scale according to pre-defined ranking criteria. The aggregated risk estimate is a combination of the semi-quantitative vulnerability indicators and quantitative estimates of the frequency of the natural hazard, the potential duration of the infrastructure malfunctioning (e.g. depending on the required restoration effort) and the number of users of the infrastructure.

All these different aspects highlight one or more issues related to vulnerability and resilience science, and they thus contribute to the overarching scientific debate on resilience and vulnerability assessments in natural hazard and risk analysis.

Acknowledgements. We would like to express our sincere thanks to the entire team of the Editorial Office at Copernicus. Moreover, we would like to acknowledge the efforts of all the reviewers who supported this special issue with their knowledge on different aspects of vulnerability and resilience in natural hazard risk management and their constructive advice that helped us and the authors to further develop the individual ideas presented in the papers. We would also like to thank all the colleagues who contributed to this Special 
Issue, above all for their patience during the process of manuscript production and revision.

\section{References}

Birkmann, J., Cardona, O. M., Carreño, M. L., Barbat, A. H., Pelling, M., Schneiderbauer, S., Kienberger, S., Keiler, M., Alexander, D., Zeil, P., and Welle, T.: Framing vulnerability, risk and societal responses: the MOVE framework, Nat. Hazards, 67, 193-211, 2013.

Castillo-Rodríguez, J. T., Escuder-Bueno, I., Perales-Momparler, S., and Porta-Sancho, J. R.: Enhancing local action planning through quantitative flood risk analysis: a case study in Spain, Nat. Hazards Earth Syst. Sci., 16, 1699-1718, https://doi.org/10.5194/nhess-16-1699-2016, 2016.

Ciurean, R. L., Schröter D., and Glade, T.: Conceptual frameworks of vulnerability assessments for natural disasters reduction, in: Approaches to disaster management - examining the implications of hazards, emergencies and disasters, edited by: Tiefenbacher J., InTech, Rijeka, 3-32, 2013.

Cutter, S., Boruff, B., and Shirley, W.: Social vulnerability to environmental hazards, Soc. Sci. Quart., 84, 242-261, 2003.

Dressler, G., Müller, B., Frank, K., and Kuhlicke, C.: Towards thresholds of disaster management performance under demographic change: exploring functional relationships using agentbased modeling, Nat. Hazards Earth Syst. Sci., 16, 2287-2301, https://doi.org/10.5194/nhess-16-2287-2016, 2016.

Eidsvig, U., Papathoma-Köhle, M., Du, J., Vangelsten, B. V., and Glade T.: Quantification of model uncertainty in debris flow vulnerability assessment, Eng. Geol., 181, 15-26, 2014.

Eidsvig, U. M. K., Kristensen, K., and Vangelsten, B. V.: Assessing the risk posed by natural hazards to infrastructures, Nat. Hazards Earth Syst. Sci., 17, 481-504, https://doi.org/10.5194/nhess-17481-2017, 2017.

Field, C. B., Barros, V. R., Dokken, D. J., Mach, K. J., Mastrandrea, M. D., Bilir, T. E., Chatterjee, M., Ebi, K. L., Estrada, Y. O., Genova, R. C., Girma, B., Kissel, E. S., Levy, A. N., MacCracken, S., Mastrandrea, P. R., and White, L. L.: Climate Change 2014: Impacts, adaptation, and vulnerability, Cambridge University Press, Cambridge, 1132 pp., 2014.

Fuchs, S., Kuhlicke, C., and Meyer, V.: Editorial for the special issue: vulnerability to natural hazards - the challenge of integration, Nat. Hazards, 58, 609-619, 2011.

Fuchs, S., Birkmann, J., and Glade, T.: Vulnerability assessment in natural hazard and risk analysis: current approaches and future challenges, Nat. Hazards, 64, 1969-1975, 2012.

Fuchs, S., Keiler, M., and Zischg, A.: A spatiotemporal multi-hazard exposure assessment based on property data, Nat. Hazards Earth Syst. Sci., 15, 2127-2142, https://doi.org/10.5194/nhess-15-2127-2015, 2015.

Fuchs, S. and Glade, T.: Vulnerability assessment in natural hazard risk - a dynamic perspective, Nat. Hazards, 82, 1-5, 2016.

Fuchs, S., Röthlisberger, V., Thaler, T., Zischg, A., and Keiler, M.: Natural hazard management from a coevolutionary perspective: Exposure and policy response in the European Alps, Annals of the American Association of Geographers, 107, 382-392, 2017.

Garcia, R. A. C., Oliveira, S. C., and Zêzere, J. L.: Assessing population exposure for landslide risk analysis using dasymet- ric cartography, Nat. Hazards Earth Syst. Sci., 16, 2769-2782, https://doi.org/10.5194/nhess-16-2769-2016, 2016.

Glade, T. and Birkmann, J.: Assessment of different dimensions of vulnerability to natural hazards and climate change, Special Volume in Nat. Hazards Earth Syst. Sci., 2009.

Greiving, S. and Glade, T.: Risk governance in: Encyclopedia of natural hazards, edited by: Bobrowsky P. T., Springer, New York, 863-870, 2013.

Hufschmidt, G. and Glade, T.: Vulnerability analysis in geomorphic risk assessment, in: Geomorphological hazards and disaster prevention, edited by: Alcántara-Ayala, I. and Goudie, A. S., Cambridge University Press, Cambridge, 233-243, 2010.

Keating, A., Campbell, K., Szoenyi, M., McQuistan, C., Nash, D., and Burer, M.: Development and testing of a community flood resilience measurement tool, Nat. Hazards Earth Syst. Sci., 17, 77-101, https://doi.org/10.5194/nhess-17-77-2017, 2017.

Keiler, M. and Fuchs, S.: Vulnerability and exposure to geomorphic hazards - some insights from mountain regions, in: Geomorphology and society, edited by: Meadows, M. and Lin, J.-C., Springer, Tokyo, 165-180, 2016.

Keiler, M., Zischg, A., Fuchs, S., Hama, M., and Stötter, J.: Avalanche related damage potential - changes of persons and mobile values since the mid-twentieth century, case study Galtür, Nat. Hazards Earth Syst. Sci., 5, 49-58, https://doi.org/10.5194/nhess-5-49-2005, 2005.

Keiler, M., Sailer, R., Jörg, P., Weber, C., Fuchs, S., Zischg, A., and Sauermoser, S.: Avalanche risk assessment - a multitemporal approach, results from Galtür, Austria, Nat. Hazards Earth Syst. Sci., 6, 637-651, https://doi.org/10.5194/nhess-6637-2006, 2006.

Keiler, M., Knight, J., and Harrison, S.: Climate change and geomorphological hazards in the eastern European Alps, Philos. T. Roy. Soc. A, 368, 2461-2479, 2010.

Komarov, A. Y., Seliverstov, Y. G., Glazovskaya, T. G., and Turchaninova, A. S.: Risk assessment in the North Caucasus ski resorts, Nat. Hazards Earth Syst. Sci., 16, 2227-2234, https://doi.org/10.5194/nhess-16-2227-2016, 2016.

Malek, Z., Boerboom, L., and Glade, T.: Future forest cover change scenarios with implications for landslide risk: An example from Buzau Subcarpathians, Romania, J. Environ. Manage., 56, 1228 1243, 2015.

Papathoma-Köhle, M.: Vulnerability curves vs. vulnerability indicators: application of an indicator-based methodology for debrisflow hazards, Nat. Hazards Earth Syst. Sci., 16, 1771-1790, https://doi.org/10.5194/nhess-16-1771-2016, 2016.

Papathoma-Köhle, M., Gems, B., Sturm, M., and Fuchs, S.: Matrices, curves and indicators: a review of approaches to assess physical vulnerability to debris flows, Earth-Sci. Rev., 171, 272-288, 2017.

Rygel, L., O'Sullivan, D., and Yarnal, B.: A method for constructing a social vulnerability index, Mitigation and Adaptation Strategies for Global Change, 11, 741-764, 2006.

Stocker, T. F., Qin, D., Plattner, G.-K., Tignor, M., Allen, S. K., Boschung, J., Nauels, A., Xia, Y., Bex, V., and Midgley, P. M.: Climate change 2013: The physical science basis, Contribution of Working Group I to the Fifth Assessment Report of the Intergovernmental Panel on Climate Change, Cambridge University Press, Cambridge, 1535 pp., 2013. 
Sudmeier-Rieux, K.: Resilience - an emerging paradigm of danger or of hope?, Disaster Prevention and Management, 23, 67-80, 2014.

Thaler, T., Priest, S., and Fuchs, S.: Evolving interregional cooperation in flood risk management: distances and types of partnership approaches in Austria, Reg. Environ. Change, 16, 841853, 2016.

Totschnig, R., Sedlacek, W., and Fuchs, S.: A quantitative vulnerability function for fluvial sediment transport, Nat. Hazards, 58, 681-703, 2011.
Willis, I. and Fitton, J.: A review of multivariate social vulnerability methodologies: a case study of the River Parrett catchment, UK, Nat. Hazards Earth Syst. Sci., 16, 1387-1399, https://doi.org/10.5194/nhess-16-1387-2016, 2016.

Willis, I., Gibin, M., Barros, J., and Webber, R.: Applying neighbourhood classification systems to natural hazards: a case study of Mt Vesuvius, Nat. Hazards, 70, 1-22, 2010. 